\title{
ОРНИТОФАУНА ЛЕСОПОЛОС СТЕПНОЙ ЗОНЫ ЦЕНТРАЛЬНОЙ ТУВЫ (РОССИЯ, РЕСПУБЛИКА ТЫВА) 1
}

\section{THE ORNITHOFAUNA OF FOREST SHELTERBELTSTHE STEPPE ZONE OF THE CENTRAL TUVA (RUSSIA, REPUBLIC OF TUVA)}

\section{S. Seveley \\ A. Saaya \\ D. Kuksina}

Summary. The material was the results of field studies in field-protective forest bands located in Central Tuva during 2006, 2016-2018. Of the 22 species found in forest bands, 11 (50\%) nest. The most numerous breeding species are Falco tinnunculus, Milvus migrans, Buteo hemilasius, Pica pica. There is a decrease in internal and interspecific competition, which causes a high density of nesting and the formation of group settlements of bird populations.

Keywords: avifauna, forest shelterbelts, steppe zone, species composition, nesting birds, rare species, Central of Tuva, Republic of Tuva.

\author{
Севелей Шончалай Сергеевна \\ Преподаватель, Тувинский государственный \\ университет (Кызыл) \\ seveley@yandex.ru \\ Саая Арияна Томур-ооловна \\ Преподаватель, Тувинский государственный \\ университет (Кызыл) \\ ariyanats@yandex.ru \\ Куксина Долаана Кызыл-ооловна \\ К.б.н., доцент, Тувинский государственный \\ университет (Кызыл) \\ kdolaana@yandex.ru
}

Аннотация. Материалом послужили результаты полевых исследований в полезащитных лесных полосах, расположенных на территории Центральной Тувы в течение 2006, 2016-2018 гг. Из 22 видов, встречающихся в лесополосах, гнездятся 11 (50\%). Самыми многочисленными гнездящимися видами являются Falco tinnunculus, Milvus migrans, Buteo hemilasius, Pica ріса. Отмечается снижение внутри и межвидовой конкуренции, что вызывает высокую плотность гнездования и формирование групповых поселений популяций птиц.

Ключевые слова: орнитофауна, лесополосы, степная зона, видовой состав, гнездящиеся птицы, редкие виды, Центральная Тува, Республика Тыва.

темно-хвойной сибирской тайги до сухих и пустынных степей суббореального пояса. По преобладанию тех или иных ландшафтов в разных частях территории Тува принадлежит к двум широтно-географическим зонам Евразии: таежно-лесной и степной (Носин, 1963). центральную Туву входят Пий-Хемский, Улуг-Хемский, Каа-Хемский, Чеди-Хольский, Чаа-Хольский, Тандинский, Кызылский районы, которые лежат в пределах Центрально-Тувинской и Турано-Уюкской котловин (Конгар, 1960)

В период с 40-х гг. XX века и до настоящего времени фауне птиц полезащитных лесополос уделялось большое внимание. В центральном регионе России полноценные результаты исследований, в Тульской и северной части Липецкой области приведены О.В Швец и др. (2013), не ослабевало внимание к данному направлению в степной зоне северо-западного Приазовья Украины,

Финансирование части работ осуществлялось в рамках гранта Российского фонда фундаментальных исследований проект№ 18-44-170003 р_а, Москва, Россия. 
где Э. М. Аюбовой (2013) отмечен 51 вид птиц. В регионах Нижнего Поволжья исследования проведены Е.А.Сухолозовым (2012). Результаты работ в степных районах Оренбургской области и Предуралья мы находим в обобщающих публикациях В.Ю Степанкиной и Э.В Гавлюк $(2009,2011)$. В Ставропольском крае исследованиям фауны птиц полезащитных лесополос приведены в публикациях Г.П.Шкарлетт (2015). М.В.Добровольским (2016) отражена история орнитологических исследований искусственных лесов европейской части бывшего CCСР.

По республике Хакасия и прилегающей территории Красноярского края - Минусинской котловине, сведения о видовом составе птиц имеются в работах Т. А. Ким (1968); Т. В. Злотниковой (2000) С.М.Прокофьева (2015).

Анализа исследований, посвященных населению орнитофауны полезащитных лесополос степной зоны России, показывает достаточно большой интерес, как в фаунистическом отношении, так и в связи с антропогенным воздействием, которое существенно повлияло на экологические условия обитания степных птиц.

Вследствие распашки степей в 60-70 гг. XX века покинули места обитания дрофа обыкновенная Otis tarda, которая впоследствии исчезла с центральных районов Тувы, сократилась численность журавля красавки Anthropoides virgo, редкими стали степной орел Aquila nipalensis, черный гриф Aegypius monachus. После развала сельского хозяйства лесополосы сформировали стации обитания для дендрофилов, таких, как балобан Falco cherrug, мохноногий курганник Buteo hemilasius, черный коршун Milvus migrans.

Целью исследований было выявление видового состава и специфики гнездящихся видов птиц полезащитных лесополос Центральной Тувы.

\section{Материал и метоника}

Материал по видовому составу птиц собран нами с 2006 г по 2018 г. на территории Тандинского и Кызылского районов $\left(51^{\circ} 24^{\prime}-51^{\circ} 54^{\prime} \mathrm{N}, 94^{\circ} 40^{\prime}-94^{\circ} 60^{\prime} \mathrm{E}\right)$ в весенне-летний период 2-3 раза в месяц. Основной метод работы - маршрутный учет встреченных птиц в пределах лесополосы (Равкин, 2008). Отдельные виды вне лесополосы также отмечались. Всего выполнено более 30 учетов, пройдено 125 км. Характер пребывания определены визуально с постоянной регистрацией. Гнездование вида считалось доказанным, если найдены гнезда, за которыми проводилось наблюдение. По результатам учетов составлен список фауны птиц. Названия птиц и порядок их расположения приведены по Е. А. Коблику и др. $(2006,2014)$.
Полезащитные лесные полосы в Туве начали создаваться в шестидесятые годы прошлого столетия. При их создании в качестве главных древесных пород чаще всего использовали быстрорастущие тополя - бальзамический (Popullus balsamifera L.), лавролистный (Popullus laurifolia Ledeb.) и вяз приземистый Ulmus pumila L. (Вараксин, 2011). Значительные площади котловины Кызылского сухостепного района заняты элювиальными песками. Большая часть их покрыта травянистой растительностью, под которой формируются песчаные каштановые почвы с довольно развитым гумусовым горизонтом, но в ряде мест пески сильно развеваются (Курбатская, 2018).

\section{Результаты и их обсужхение}

Видовой состав орнитофауны полезащитных лесополос в степной зоне Центральной Тувы по нашим данным насчитывает 22 вида, из них гнездятся 11 (50\%). По структуре населения популяций птиц данных территорий приведены в ранее вышедшей публикации (Куксина и др., 2020). Ниже мы приводим обзор видов и их эколого-биологические особенности гнездования.

Falco tinnunculus многочисленный, гнездящийся вид. С зимовок прилетает после освобождения степей от снега. Птицы чаще всего занимают старые гнезда ворон, сорок и других птиц на деревьях. Высота расположения гнезд F.tinnunculus варьирует от 2,5 м до 6 м на вязе приземистом и тополе лавролистном. Гнезда пустельги располагают достаточно близко, наименьшее расстояние между соседними гнездами составляет 9 м. Количество яиц от 4 до 5 (в среднем 4,3), эффективность выживания птенцов - $94 \%$.

Milvus migrans обычен, местами даже многочислен. Весенний прилет приходится в период больших проталин и снеготаяния, чаще всего возвращается к своим старым гнездам. Под гнездом хищника гнездились P.montanus (рис. 1). Располагает гнезда на тополе лавролистном на высоте от 2,6 до 7 м.

Самка откладывает яйца в последних числах апреля или в первой половине мая, в зависимости от условий погоды. Полная кладка состоит из 2-3 яиц, в среднем 2,5, эффективность выживания птенцов составляет 88\%.

Buteohemilasius полуоседлый, гнездящийсяобычный вид. Начало гнездования растянут, оставшаяся на зиму часть популяции начинает гнездиться раньше, примерно во второй половине апреля. Гнезда $B$. hemilasius расположены на вязе и тополе, на высоте от 2,3 до 6,5 м. Откладка яиц начинается с 20 чисел апреля, в кладке от 2 до 4 яиц, эффективность выживания птенцов 87\%. Птенцы появляются в первых числах июня. Молодые птенцы 


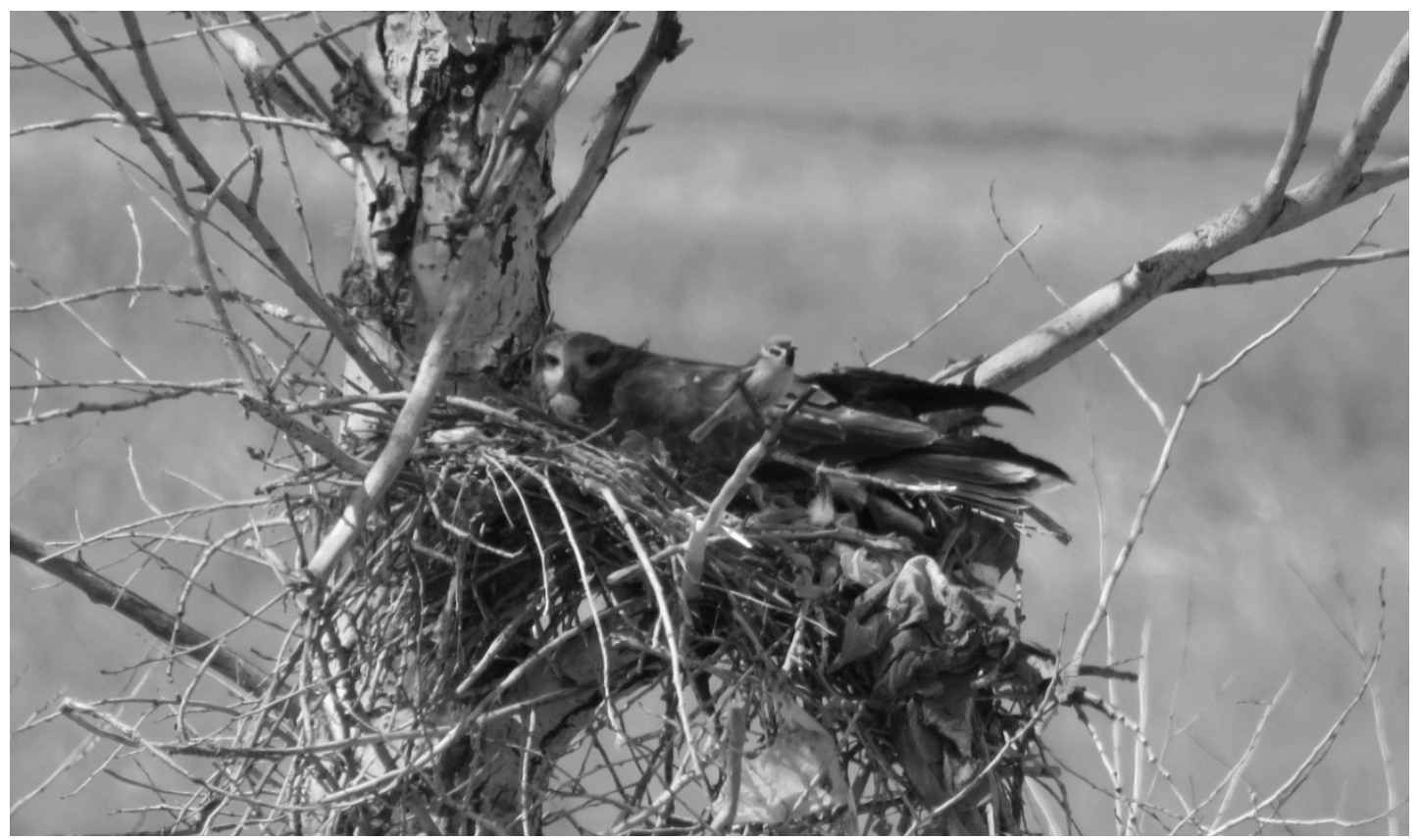

Рис. 1. M. migrans, внизу гнездо Р. montanus.

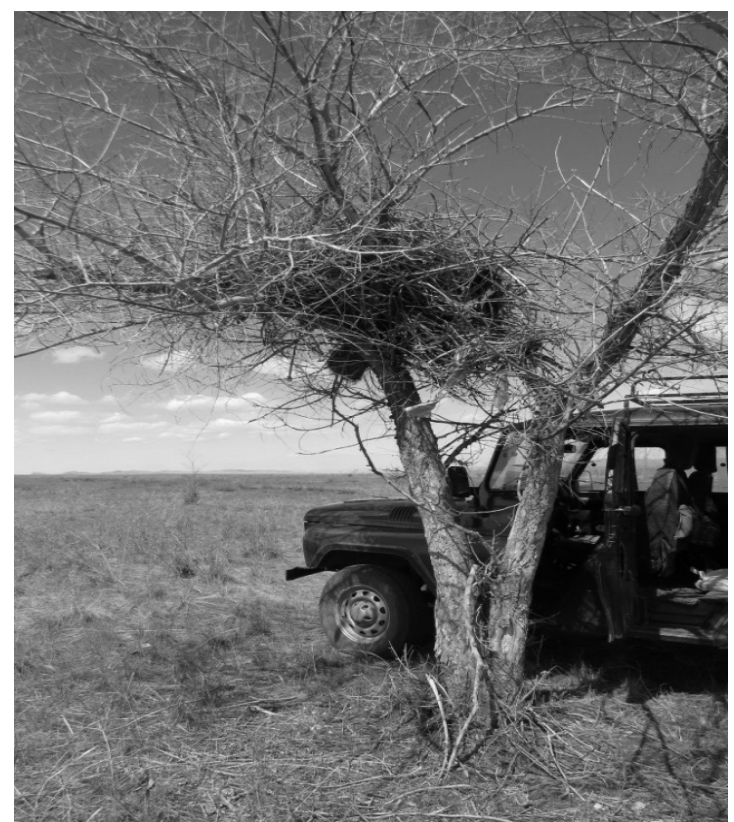

Рис. 2. Гнездо F. cherrug на U. Pumila

вылетают из гнезд в середине июля. Гнездовой период тянется около 45 дней. Материал гнёзд у M. Migrans и $B$. hemilasius отличается от остальных хищников наличием полиэтиленовых пакетов и мешков, хозяйственных перчаток, кусков ткани, шерсти.

Falco cherrug сокращающийся в численности вид, занесенный в Красный Список IUCN в категории «EN»

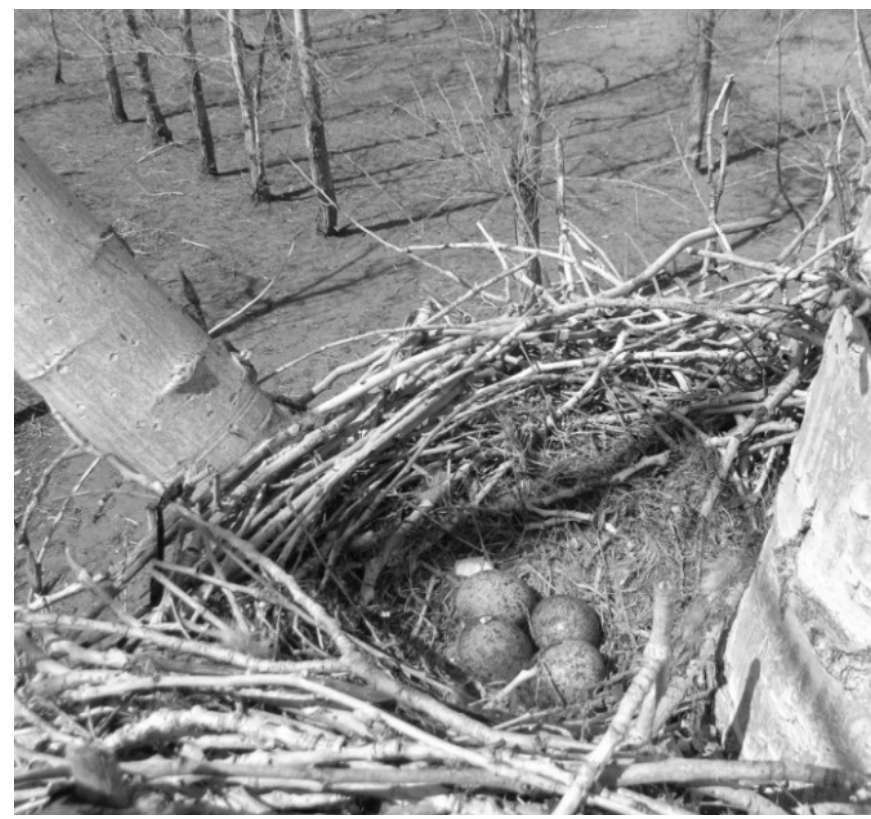

Рис. 3. Яйца F. cherrug на P. laurifolia

(2019), вид, находящийся под угрозой исчезновения, Красную книгу Российской Федерации (2001) и Республики Тыва (VU) (2019). Гнездовые участки постоянны, используются много лет подряд. Гнёзд не строит, занимая гнёзда других птиц. Нами были найдены гнёзда на вязе и тополе на высоте от 2,5 до 3,5 м (рис. 2). Во второй половине апреля самка откладывает от 3 до 4 яиц (рис. 3). 
После 10-12 мая появляются птенцы, выживаемость птенцов доходит до 90\%, с середины июня - летные молодые. На вязе, сидящая на яйцах самка отлетела от гнезда, подпустив человека на 3 м. В гнёздах были найдены остатки пищухи Ochotona alpina, на земле остатки шерсти лисицы Vulpes vulpes.

Falco naumanni прилетает во второй половине апреля-начале мая. Гнездятся на скалах одиночных гранитных останцах, каменистых склонах, в нагромождениях камней. В кладке чаще 4-5 яиц, которые насиживают самка и самец около месяца, птенцы выкармливаются в гнезде 35-40 дней. В лесополосах обычно сидят на присадах, охотится на пищух в залежах. В регионе уязвимый, сокращающийся в численности вид (VU), занесен в Красную книгу Российской Федерации (2001) и Республики Тыва (2019).

Circus cyaneus обычный, местами редкий вид. С появлением больших проталин начинают прилетать поодиночке. Отмечался в залежных землях между лесополосами. Гнездо устраивает на земле в высокотравье, среди кустов караганы карликовой. Самка откладывает от 3 до 5 яиц.

В гнездах хищников гнездится $P$. montanus, так, на тополе под гнездом $B$. hemilasius располагалось гнездо $F$. tinnunculus, и под ним еще гнездились $P$. montanus.

Pica pica многочисленный вид, является основным поставщиком гнезд для хищников. Гнездятся на тополях и вязах на высоте от 5 до 7 м от земли. В гнезде от 7 до 10 яиц, чаще 7-8. Большая часть молодых птиц покидают гнезда в первой декаде июня.

Corvus corone обычная, гнездящаяся птица. Предпочитают насаждения с участием тополя лавролистного, обычно в кладке 4-6 яиц.

Corvus corax встречается редко, в лесополосах не гнездится.

Upupa epops обычный, гнездящийся перелетный вид. Наиболее обычны в степи, где есть обрывы, нагромождения камней. Появляется весной во второй половине апреля - начале мая. Гнездится в пнях повалившихся тополей, под грудами камней и под частями брошенной сельхозтехники. Самка откладывает от 5 до 8 яиц.

Perdix dauurica обычная, местами многочисленная птица. Пары начинают формироваться в марте-апреле, размножение птиц длится с марта по июль. Гнездится в лесополосах, где доминирует вяз, с зарослями сорных трав, караганы карликовой. Гнездо устраивают на земле, под прикрытием кустов или травы, с растительной выстилкой, в гнезде от 14-20 яиц.
Anthropoides virgo на места гнездования появляется парами, прилетает во второй декаде апреля. В регионе встречается массово, численность стабильная, занесен в Красную книгу РФ (2001) и РТ (2019) как редкий вид (LC). Период весеннего пролёта охватывает 2-3 недели и заканчивается в первой декаде мая. Красавка гнездо устраивает на сухих местах с щебнистым грунтом. Во второй половине мая самка откладывает 2 яйца, вылупление птенцов начинается с середины июня и длится до 20 чисел.

Alauda arvensis в окрестностях лесополос появляется с первыми проталинами в марте-начале апреля. Гнезда найдены на земле в естественном углублении, под прикрытием кустика травы. Начало откладки яиц в гнёздах растянут, в кладке 4-5 яиц. Птенцы покидают гнездо в возрасте 8-10 дней.

Eremophila alpestris обычный, оседлый кочующий вид, весной начинает спускаться с гор в конце февраля, массовая кочевка наблюдалась в середине марта. Гнездо устраивает на земле под незначительными неровностями земли, камнями, прикрытыми пучком злаков. Гнезда выстланы травой, конским волосом, шерстью овец. В полной кладке 3-5 яиц. Небольшими стаями собираются осенью и кочуют по степи.

Anthus campestris более ксерофильный вид, предпочитает сухие, каменистые опустыненные участки степи с редким травостоем. Отмечен в конце апреля начале мая. Гнезда найдены в местах со скудной растительностью. Откладывание яиц происходит с конца мая до середины июня. Кладка состоит из 3-6 яиц. В августе начинается отлет, который заканчивается к середине сентября.

Motacilla personata прилетают ранней весной в конце февраля, в начале марта. Самцы появляются раньше самок и занимают территории для гнездования. Расположение гнезд разнообразное: в густых кустах и в пустотах на нагромождениях камней. В кладке 5-6 яиц. Отлет происходит постепенно, с конца лета до поздней осени.

Lanius isabellinus прилетает поздно, в серединеконце мая. Гнездятся в сухих кустарниках на всхолмленных участках степи, в зарослях колючих караган. Материалом служат прутики, стебли, а также шерсть (ее бывает много). Лоток выстлан тонкими стеблями травянистых растений, корешками, шерстью и лубом. В июне самка откладывает от 5 до 6 яиц. Птенцы сидят в гнезде 13-14 дней. В конце августа 2017 г. были отмечены 4 слетка L. isabellinus в лесополосе из вяза, где на ветках были наколоты прямокрылые, недалеко от птенцов сидели взрослые особи. 
Saxicola torquata появляется в апреле - начале мае стайками в 15-25 птиц. В залежах доминирующий вид. Гнезда располагают на земле. В кладке 4-6 яиц и насиживает их 11-14 дней. Птенцы вылетают из гнезда в начале июня - конце июля. Последние птицы зарегистрированы в конце августа.

Oenanthe isabellina обычный, местами многочисленный вид. Весенний прилет наблюдался в начале второй декады апреля. Устраивают свои гнезда в старых норах барсуков, пищух, также в щелях между камнями. Птенцы покидают гнездо в возрасте около 2 недель. В сезон два выводка.

Oenanthe oenanthe прилетает раньше всех остальных каменок, в конце схода снега в апреле. Гнездо устраивает в щелях среди нагромождения камней. Птенцы покидают гнездо в возрасте 12-16 дней. Осенний пролёт каменок начинается в августе, последние птицы отмечены в первой декаде октября. Обычно два выводка в сезон.

Asio otus появляется в марте-апреле, гнездится в лесополосах, занимает старые гнезда сороки. В кладке обычно 4-5 яиц. Чаще становятся жертвами балобана, как взрослые птицы, так и птенцы. Выживаемость птенцов $50-60 \%$.

Следующие виды Phylloscopus fuscatus и Tarsiger cyanurus, не характерные для степных биоценозов, отмечались нами единично весной на пролете.

Популяции птиц разреженных лесополос Центральной Тувы обладают рядом экологических особенно- стей. Так, при недостатке стаций для устройства гнезд снижается внутривидовая и межвидовая конкуренция, что вызывает высокую плотность гнездования и формирование групповых поселений $F$. tinnunculus. Также наблюдается совместное гнездование $M$. migrans и $P$. montanus. Лесополосы являются экологическим руслом для мигрирующих птиц и играют роль для расселения лесных видов в степи. Играют важную роль в поддержании стабильности популяций охраняемых видов птиц: $F$. cherrug, F naumanni и $A$. virgo.

\section{Зак^ючение}

В условиях сухих и опустыненных степей Центрально-Тувинской котловины лесные полосы создают подходящие условия для обитания 22 видов птиц. Несмотря на небольшую ширину и изреженность территории искусственных лесных полос в условиях сухостепной зоны Тувы, мы отмечаем богатый видовой состав и высокую плотность населения птиц. Характерно смешение разных экологических группировок на небольших площадях.

Таким образом, полезащитные лесополосы в экстремально аридных условиях играют важную роль в сохранении и обогащении биоразнообразия, в поддержании стабильности популяций редких видов, представляют собой «экологические коридоры» для мигрирующих птиц и расселения многих лесных форм в зональные степи. Наблюдается зависимость разнообразия орнитофауны данных сообществ от степени трансформации окружающих ландшафтов, что предопределяет необходимость дальнейших исследований

\section{ЛИТЕРАТУРА}

1. Аюбова Э. М. Формирование орнитофауны искусственных лесополос и лесов Северо-Западного Приазовья // Вісник Запорізького національного університету. Біологічні науки.—2013.— № 2.C. 16-27. URL: http://nbuv.gov.ua/UJRN/Vznu_bio_2013_2_5 (дата обращения 22.09.2019).

2. Вараксин Г.С., Лобанов А. И., Шангова 0. Г., Вараксина С. Г. Устойчивость лесных полос на пахотных землях в степных условиях Республики Тыва // Вестник Красноярского государственного аграрного университета. Экология. Красноярск, 2011.-Вып.6. С. 94-97.

3. Гавлюк Э.В., Степанкина В. Ю. Видовая структура населения птиц лесополос степного Предуралья // Известия Оренбургского государственного аграрного университета. 2011.— - Т. 1, № 29 (1). С. 224-226.

4. Добровольский М. В. Исторические аспекты и тематическая направленность орнитологических исследований полезащитных лесных полос России и Украины //Русский орнитологический журнал2016. - Т. 25, Экспресс-выпуск 1333: С. 3286-3295. URL: https://ornis.su/downloads/category/24-2016.html (дата обращения 26.03.2020)

5. Злотникова Т.В. Кэкологии птиц сельскохозяйственных ландшафтов Хакасии в зимний период // Животное население и растительность бореальных лесов и лесостепей Средней Сибири: Межвузовский сборник научных трудов. Красноярск: РИО КГПУ. 2000.—- Выпуск 1. С. 71-78.

6. Ким Т.А. К экологии птиц железнодорожных лесополос в Хакасии // Вопросы зоологии. Проблемы высшей нервной деятельности человека и животных. Красноярск, 1968.- С. 35-40.

7. Коблик Е.А., Редькин Я. А., Архипов В. Ю. Список птиц Российской Федерации. М.: Товарищество научных изданий КМК, 2006. - 281 с.

8. К Коблик Е.А., Архипов В. Ю. Фауна птиц стран северной Евразии в границах бывшего СССР. Списки видов. Зоологические исследования № 14. М.: Товарищество научных изданий КМК, 2014-172 с.

9. Конгар Н. М. Соколов В. А., Сонам С. С., Шелемотов В.С. Система ведения сельского хозяйства в Туве / под ред. П. Ф. Иванова., А. А. Козленко. - Кызыл.: Тувинское книжное издательство, 1960-267с. 
10. Красная книга Республики Тыва (животные, растения и грибы). — 2-е изд. доп и перераб. / отв. ред. С. О. Ондар, Д. Н. Шауло. Воронеж, 2019. — 560 с.

11. Красная книга Российской Федерации (животные). Балашиха: Изд-во Астрель, Агинское: Изд-во АСТ; 2001. — 860 с.

12. Куксина Д.К., Севелей Ш. С., Саая А. Т. Население птиц полезащитных лесополос Центрально-Тувинской котловины // Вестник Тувинского государственного университета. 2020.—- Выпуск № 2 (61). С. 14-22.

13. Курбатская, С. С. Гуркова Е. А. Почвенный покров // Природные ресурсы Республики Тыва. Т. І. Новосибирск: Изд-во Гарамонд, 2018. — С. 213.

14. Носин В. А. Почвы Тувы.— Москва: Изд-во АН СССР, 1963.— 342 с.

15. Прокофьев С. М. Состав и структура населения птиц полезащитных лесных полос Минусинской котловины // Русский орнитологический журнал. 2015.Т. 24, Экспресс-выпуск 1174. С. 2795-2797.

16. Равкин Ю.С., Ливанов С. Г. Факторная зоогеография: принципы, методы и теоретические представления.—Новосибирск: Наука, 2008. — С. $49-71$.

17. Рельеф Алтае-Саянской горной области / Г. А. Чернов, В. В. Вдовин, П. А. Окишев и др.—Новосибирск, 1988-206 с.

18. Степанкина В.Ю., Гавлюк Э. В. Видовой состав и биоценотические связи птиц лесных полос и агроценозов Степного Приуралья // Вестник Оренбургского государственного университет. 2009.— № 6. С. 357-361.

19. Сухолозов Е. А. Птицы искусственных лесонасаждений Нижнего Поволжья: видовой состав, распределение, гнездование. Автореферат на соискание канд. биол. наук.— Москва, 2012.— 23 c. URL: https://www.dissercat.com/content/ptitsy-iskusstvennykh-lesonasazhdenii-nizhnego-povolzhya (дата обращения 26.03.2020).

20. Швец О. В., Воронецкий В. И., Двуреченская С. О. Авифауна лесополос некоторые особенности распределения птиц в центральном регионе России у границ лесной и лесостепной зон // Известия Тульского государственного университета. Естественные науки. 2013.— № 1-2. С. $306-318$.

21. Шкарлетт Г.П. Фауна и население птиц полезащитных насаждений Ставропольского края // Биологические науки «Наука. Инновации. Технологии». 2015. — № 2. C. 187-196.

22. Bird Life International 2017. Falco cherrug (amended version of 2016 assessment). The IUCN Red List of Threatened Species 2017: e.T22696495A110525916 http:// dx.doi.org/10.2305/IUCN.UK.2017-.RLTS.T22696495A110525916.en. (accessed: 08.10.2019).

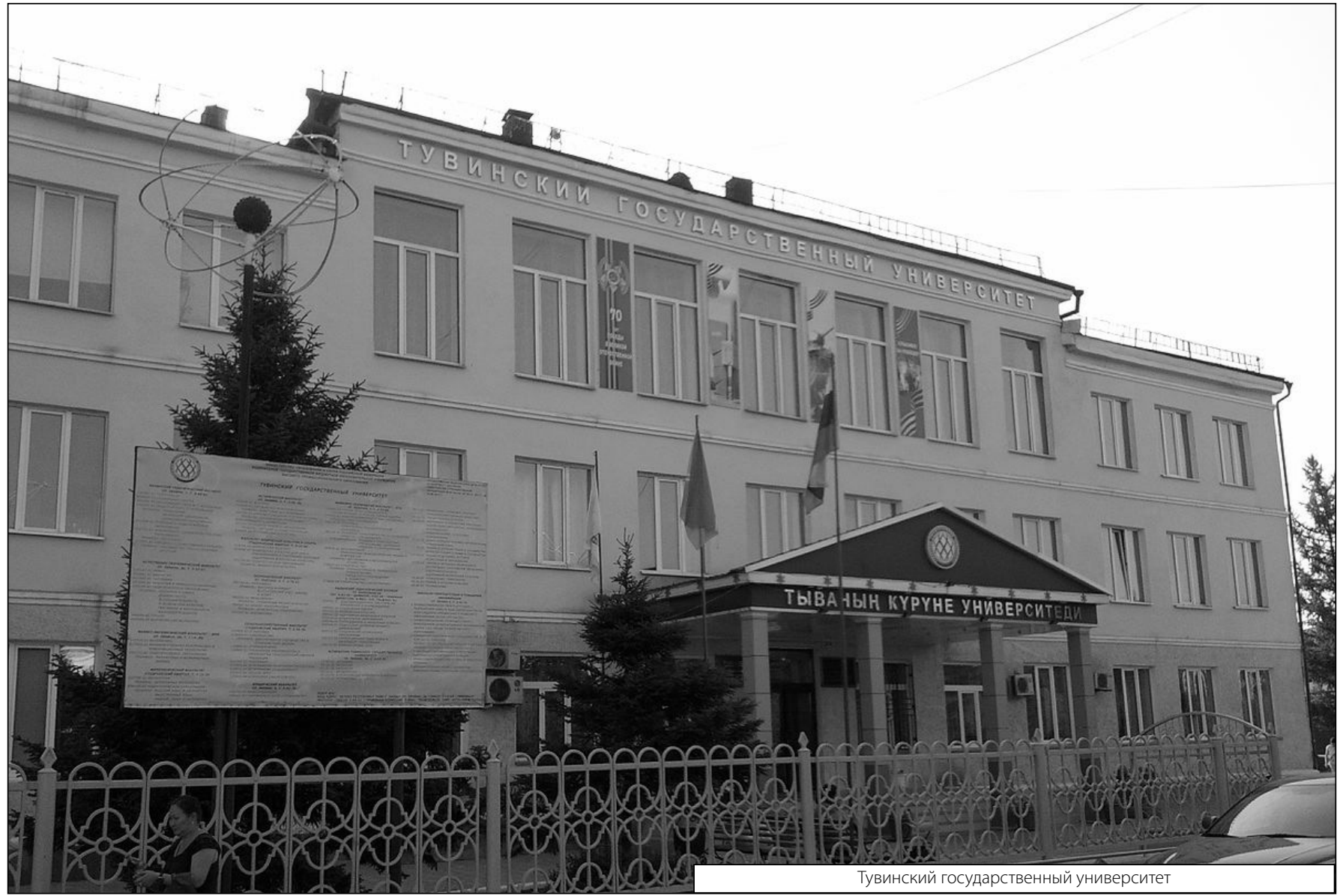

